\title{
Economic Indicators as Public Interventions
}

Gil Eyal and Moran Levy

The main argument of this essay is that the term public intellectual is too narrow for historical research about the public influence of economists and economic expertise. We propose, instead, the concept of public interventions to inform a more comprehensive approach, one that broadens the analytical frame by multiplying the relevant actors, modes, and targets of intervention yet could still include within it research on public intellectuals narrowly construed. As an empirical example, we suggest that the design and diffusion of economic indicators-specifically, the GDP and the myriad indicators compiled in recent years as part of proposals to replace it with a better representation of human welfare-could be analyzed as a specific mode by which economists intervene in and shape the public sphere. This argument, about the profound influence wielded by those who design economic indicators, has of course been made by many others-especially feminists-before us (Alonso and Star 1987; Berkowitz 1996; Block and Burns 1986; Folbre 1989; Waring 1988). Its significance here is merely in demonstrating the wide terrain that opens up for historical and sociological analysis once we broaden our scope from intellectuals to interventions.

Correspondence may be addressed to Gil Eyal, Department of Sociology, Columbia University, 606 West 122nd Street, New York, NY 10027; e-mail: ge2027@gmail.com. The authors would like to thank Nitza Berkowitz, Daniel Breslau, Marianna Laura Heredia, Tiago Mata, Yuval Yonay, and the three anonymous reviewers for $H O P E$.

History of Political Economy 45 (annual suppl.) DOI 10.1215/00182702-2311007

Copyright 2013 by Duke University Press 
The approach we propose is inspired by Michel Foucault's (2000) distinction between the "universal" and "specific" intellectual; Pierre Bourdieu's ([1992] 1996) replacement of the latter by a "collective intellectual"; and the approach to the public sphere urged by the contributors to Making Things Public (Latour and Weibel 2005). Additionally, our suspicion that the concept of public intellectual is too narrow for capturing the specific way in which economists intervene in public affairs follows in the footsteps of the many sociologists of economics who have tried to analyze how economic expertise is deployed to shape public affairs, or how it "preforms" the economy (Breslau 1998, 2003; Callon 1998; Foucault 1991; Fourcade 2009; MacKenzie, Muniesa, and Siu 2007; Mitchell 1998; Rose, O’Malley, and Valverde 2006; Yonay 1998).

In the first section of this essay, we elaborate this argument in theoretical terms. We provide a brief genealogy of the concept of public intellectual, to explain why it is too narrow for present purposes. Then we draw on Foucault, Bourdieu, and others to develop an analytical framework for research on interventions, distinguishing between agencies, modes, and targets of intervention. In the second section, we argue that this approach, focusing on interventions rather than intellectuals, is especially suited for guiding research on the public deployments of economic expertise. In the third section, we offer a brief history of the origins of the GDP (and of the system of national accounts more generally), aiming to substantiate our treatment of it as a specific target of public intervention by economists. The fourth and final section analyzes the now four-decades-long collective attempt to provide a summary index of human welfare and economic progress that could replace, supplement, or correct GDP, as such public interventions.

\section{From Public Intellectuals to Public Interventions}

A concept like public intellectual cannot be just picked up ready-made to be used for analytical purposes. It trails behind it a long history of uses and abuses that is activated every time one deploys it unawares. The concept of intellectual in its modern meaning was invented during the Dreyfus affair (1894-1906). It was not coined for analytical or diagnostic purposes but as a political mobilizing device, a rallying call designed to bring into being the very category it was naming. Moreover, it was an exercise in self-definition, since those who issued the call considered themselves to 
be the best representatives of the category and addressed it to the likeminded (Bauman 1987, 2-8). The later career of the concept involved a continuous tangle between those who wanted to give it objective analytical meaning and extend it to wider circles of the educated, and those who sought to redraw the boundary between who is and who is not a "true" intellectual. This boundary work (Gieryn 1999) often took the form of accusations that intellectuals have betrayed their "true" mission (Benda [1927] 1928), and it ultimately informed a problematic of allegiance that pervaded all the later attempts to give the concept an objective analytical meaning (Eyal and Buchholz 2010).

Within this history, the concept of public intellectual plays a very specific role. The first point to note is that it is a very recent construction. As can be seen in figure 1, the conjunction public intellectual hardly existed before 1987, when, no doubt, the publication of Russell Jacoby's book The Last Intellectuals marked the moment when the term came into ever-widening circulation. ${ }^{1}$

The second point to note is a certain touch of redundancy in the conjunction public intellectual: are not intellectuals precisely those who in their writing and speaking appeal to a broad public? Is not the notion of public intervention and public audience already contained in the term intellectual? What exactly is done by adding the qualifier public? This peculiarity can be understood only against the background of the history of the concept, as noted above. This history is characterized by continuous attempts to extend the category of intellectuals to characterize a larger "new class" composed of experts, reaching a peak in the late 1970s (Bruce-Briggs 1979; Gouldner 1979; Konrad and Szelenyi 1979; Walker

1. For comparison's sake, the term intellectuals without qualifiers entered English-language discussions during the first decade of the twentieth century (following the Dreyfus affair), enjoyed a steady climb, and peaked around 1970. Discussions of "intellectuals" then declined till 1985, when they picked up again and by 1995 returned to 1970 levels. We suspect that the coining of the term public intellectual revived the interest in intellectuals more generally, for reasons explained in the text above: see the Ngram we constructed using Google Books at books.google.com/ngrams/graph?content=public+intellectual\%2Cintellectuals\&year_ start $=1880 \&$ year_end $=2000 \&$ corpus $=0 \&$ smoothing $=1$ (accessed November 8,2012 ). To test whether these results are robust, we also conducted a similar search on JSTOR. We found that the conjunction public intellectual appears in the title of 67 articles, the first of which is from 1988 and is a review of Jacoby's book. It had never been used in the title of an article before. The conjunction appears in the full text of 2,769 articles, only 62 (2.2 percent) of which precede 1987. A textual check shows that in the majority of these 62 articles the conjunction does not identify an individual or a social role but is a different, unrelated usage (e.g., "public intellectual life" or something similar). 


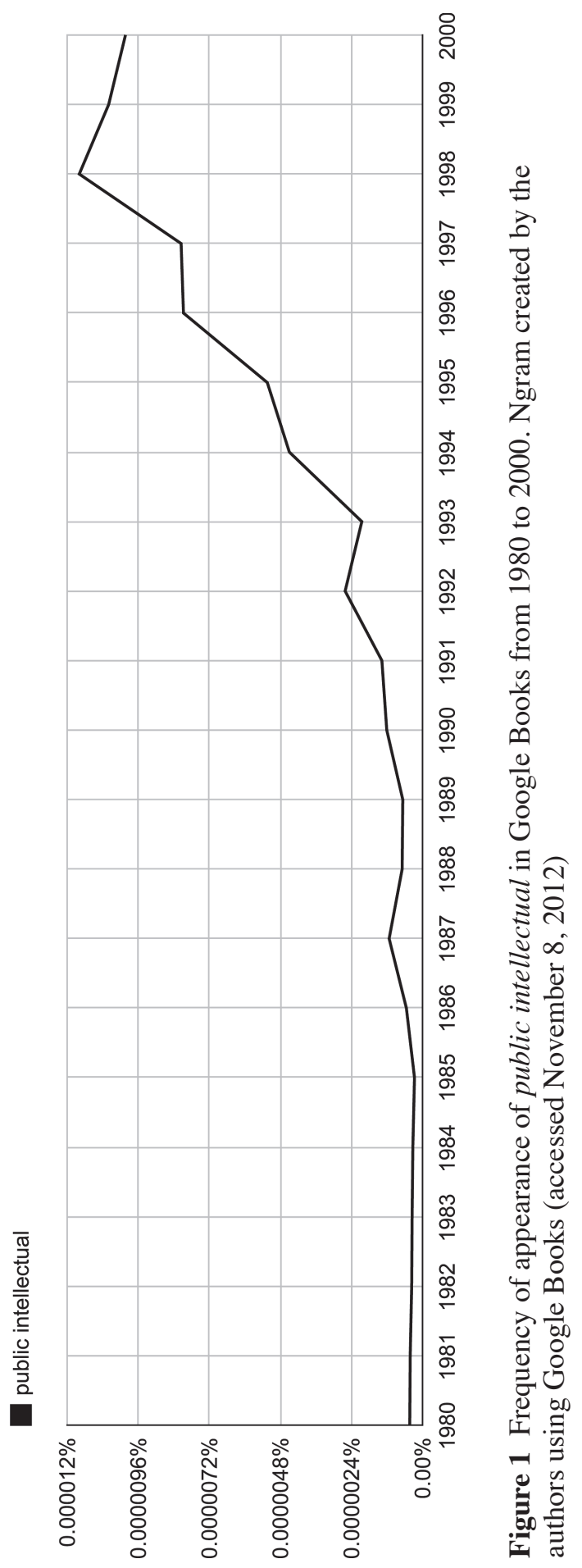


1979). Adding the qualifier public, therefore, was boundary work meant to exclude experts from the category and to signal that true intellectuals are not experts: they are not entangled in mundane technical affairs but address a broad public, owing allegiance only to truth and universal values. Since this conjunction first appeared in a book titled The Last Intellectuals, a book that belonged in the genre of jeremiad (mixture of lament and accusation) about the decline of true intellectuals and betrayal of their original mission (Posner 2001), it activates not only boundary work from experts but also a whole narrative about decline, "endangered species," the threat of betrayal (by turning expert), extinction (by a society of expertise), and consequently a debate about whether public intellectuals are disappearing or reappearing on the Web and the blogosphere (Donatich 2001; Fuller 2004; Kellner 1997). Using this term with respect to economists - who are first and foremost technical experts, whatever else they are, and for whom the diagnostic problem is not to understand a decline in their public role, but on the contrary a broadening and increase of their influence (Markoff and Montecinos 1993)-dooms the analysis in advance. It privileges a narrow focus on speech acts that have been intentionally framed as nontechnical (via their mode and site of delivery, via the prominence claimed by their authors), although in reality they always reference the technical, whether explicitly or implicitly, and could not be efficacious without it.

Fortunately, the history of writing about intellectuals affords us with a more productive alternative, represented by Foucault's $(2000,128)$ distinction between the universal and specific intellectual. While the classic "universal" intellectual fits the mold of what is meant by "public intellectual"- the prototype is represented by the engaged man of letters (Émile Zola, Jean-Paul Sartre) who speaks in the name of truth and universal values-the specific intellectual is an expert. Foucault's example of a "specific intellectual" is Robert Oppenheimer. Oppenheimer, says Foucault, was an individual whose narrow technical work as expert acquired universal dimensions when it threatened the whole human species with extinction, and who consequently was compelled to intervene in public affairs. Foucault concludes, therefore, that there is no reason to draw a strong distinction between intellectuals and experts: "The intellectual is simply the person who uses his knowledge, his competence and his relation to truth in the field of political struggles." Put differently, what is common to all who may be termed "specific intellectuals" is not that they correspond to a specific social type (since experts come in many different forms and shapes), but the movement by which their local and technical 
knowledge acquires a more general and public value and becomes the basis for an intervention in public affairs. The case of Oppenheimer, once again, is instructive. Oppenheimer did not begin as the independent, engaged critic that he came to embody later. He started as an expert working in the service of the state, first at the Manhattan Project, and then as chairman of the General Advisory Committee to the Atomic Energy Commission (AEC). It was from this position that he began lobbying for international arms control, that is, that he began intervening in public affairs. Eventually, his activism led to the revocation of his security clearance in 1954 during the heyday of McCarthyism, and he became a bona fide dissident intellectual. What is interesting about Oppenheimer surely is not this final result but the movement that took him from technical concerns and state service to increasingly independent intervention in public affairs. What Foucault did was not to add another type but to draw analytic attention to the enduring element in the concept of intellectual, the part that is indifferent to boundary work and classificatory struggles, and that could serve as a basis for reconstructing the concept.

Once we focus on this enduring element, namely, the movement by which knowledge acquires value as intervention in public affairs, we can see that given the right preconditions or precipitating events many different actors and social types could play this role. In fact, why should the agents of intervention be only individuals? Why not also groups, collectives, even organizations? This was Bourdieu's ([1992] 1996) criticism of Foucault. In contemporary conditions, he said, the agent of public intervention is most often a "collective intellectual," a group of experts working together. The same message comes from the literature on "epistemic communities" (Haas 1992). Broadening the field of investigation in this way reveals the "public intellectual" to be merely shorthand for one specific actor laying claim to one specific mode of intervention-typically the manifesto, the signed petition, the polemical op-ed piece (and now the blog), the gesture of "revelation," prophesying, "speaking truth to power," as well as propounding "transformative ideas" (Bell 1960; Gouldner 1975-76; Bauman 1987)-in one specific type of public arena.

Instead of research focusing on a certain social (and normative) type, asking whether individual economists fit this mold, as some essays in this volume do, it would be far more profitable to analyze the movement by which economic knowledge and expertise are mobilized to inform a value-laden intervention in the public sphere. In this essay, we would like to draw on earlier work (Eyal and Buchholz 2010) to propose a conceptual framework suitable for this type of analysis: 
1. Agencies of intervention: The term public intellectual tends to privilege the actions and pronouncements of a few prominent figures. As noted earlier, this inevitably leads to boundary work, and can often degenerate into hagiography or into its opposite, a narrative of decline and betrayal. Instead, we suggest several ways of widening the category of relevant actors into multiple agencies of intervention: first, we follow Bourdieu in considering not only individuals but also collectives of practitioners, networks constituting epistemic communities, even organizations such as think tanks. Second, inevitably this means that the analysis includes not only the glamorous and well-known individuals but the crowds of more "gray" practitioners, who often work together in such collectives away from the spotlight enjoyed by prominent figures. Yet, arguably, the public impact of their collective work is no less profound. Finally, we analyze all these agencies-individuals and collectives -in relation to one another, as coexisting and interdependent in a field of competition and contestation over the claim to represent publicly relevant knowledge or the proper mode of engaging with public affairs (Sapiro 2009).

2. Modes of intervention: The term public intellectual, as noted above, privileges a particular way of making such claims and of influencing public affairs. Public intellectuals intervene by means of writing op-eds, speaking in public, petitioning, or blogging. Put differently, they intervene by making their opinion known and seeking to influence the opinions of others. This seems to us an impoverished vision of what it means to intervene in public affairs. Often "it is precisely the most technical social science that has the most important political effects, even more so because those political effects are generally not recognized as such" (Breslau 1998, 39-40). We think that Foucault's point about "specific intellectuals" was precisely about a movement that takes one from the problems and contestations encountered at the technical level to the "political effects" of these technicalities. It follows that intervention could be also in the form of a report, a technical document, expert testimony, even an experimental demonstration (properly publicized), or-as we shall emphasize here-in the form of a "politics of measurement," by modifying how matters of public concern are quantified, measured, and represented (Porter 1995; Breslau 1998; Alonso and Star 1987; Block and Burns 1986). The crucial point is that the format or mode of intervention can take many different forms besides the 
publication of one's written or spoken opinion, and that often the most efficacious interventions either come black-boxed as charts, figures, numbers, and other technical devices, or they are counterstrategies that aim precisely to open up these black boxes and make the technical public and political.

3. Arenas/targets of intervention: The concept of public intellectual carries with it a certain normative (Habermasian) vision of its target as a public sphere of opinion or a sphere of public opinion. This is the main reason why the concept of public intellectual often comes coupled with a narrative of decline and betrayal, especially in the United States, because influencing, orchestrating, even creating public opinion has become the business of think tanks and they are much better at it than intellectuals. It is not a coincidence that the concept of public intellectual was coined in the mid-1980s, a time marked by the ascendency of second-generation think tanks in the American polity, who have professionalized the work of producing opinions and of producing individuals who present an opinionated posture as a way of living-pundits, commentators, "talking heads" 2 -as well as the work orchestrating and creating "public opinion" using modern PR techniques. These organizations crowd out, speak over, or buffer the interventions of independent intellectuals (Medvetz 2012). ${ }^{3}$ But there is a more fundamental (and less American-centric) reason why this vision of a public sphere of opinion is inadequate. The posture of the public intellectual references an agora populated by reasonable citizens, who are presented with conflicting opinions and are capable of adjudicating between them according to the force of the better argument. The conversation in this agora hardly ever gets technical, and when it does, the suspicion is that somebody is obfuscating, evading the debate, using scientific jargon and technical details as ideology (Habermas 1970). Modern-day politics, however, are increasingly about technical affairs of which "the public" is ignorant. This has led Walter Lippmann to declare the public a "phantom" and others in the interwar years to say that public opinion does not exist or that democracy founded on public opinion is a sham masking the rule of

2. In a play on the old Weberian distinction, we could say that intellectuals live "for opinion," while pundits (and think tanks) live "of opinion."

3. Philip Mirowski and Edward Nik-Khah (in this volume) demonstrate the extent to which actors within this buffer zone can completely block, distort, or disarm the interventions made by scientists and academics. 
experts (Lippmann 1922, 1927; Dewey 1927; Marres 2005; Binkley 1928). The point, however, is more subtle. The point is that "opinion" is a very limited way of understanding what constitutes the target of public intervention. Concerning technical matters of public concern, intervention cannot be efficacious without being equipped with all that makes expertise strong, and that opinion by itself lacks, namely, techniques, instruments, demonstrations, figures, charts, numbers. ${ }^{4}$ We show, indeed, in the next section, how public intervention is crafted by collectives of experts and laypeople, who educate themselves about a technical matter of public concern (the experts need educating too! They are often quite ignorant about newly emerging matters of concern) and equip themselves with the knowledge and the technical means to craft an intervention. This means, however, that we have to think in terms of a very different image of the public sphere. It cannot be this open homogeneous space of pure discussion. But nor can it be the closed, quasiprivate space of the laboratory. We must think of it as a channel, or more precisely multiple channels, in Bruno Latour's $(2005,19)$ terms, "the frail conduits through which truths and proofs are allowed to enter the sphere of politics." Put differently, if there are public interventions it is because there are already established "ports into the Leviathan," so to speak; there are already institutionalized conduits by means of which particular types of expertise are permanently connected to the state. In our new and admittedly strange topology, the public sphere, or spheres, is not outside the state but within its boundary, within fuzzy and thick interfaces where expertise and the state interpenetrate and blend into each other (Mitchell 1991; Rose 1992). These interfaces constitute multiple public spheres of sorts, that is, targets of public intervention that are directly continuous with the work of experts. The conversation in this space is almost always technical, but not because it is obfuscating; on the contrary, as Latour (1987) puts it about science, "when controversies flare up, the literature gets technical," namely, it is precisely in the technical details that one finds the politics, the opinions, and the values. Recall the example of Oppenheimer: he first intervened in public affairs not from outside the state but from

4. This observation is closely related to Posner's $(2001,72)$ argument that the production and circulation of public intellectual commentary suffers from a "market failure" because of low barriers to entry and poor quality control that is unable to encourage market exit. 
inside it (the Manhattan Project) or from inside its boundary (the advisory committee to the AEC). Perhaps what befell Oppenheimer the man is less significant than the institutional link he helped forge, the fact that the Advisory Committee to the AEC constitutes an institutional interface between nuclear physics and the state. The intervention of physicists in public affairs about nuclear matters need not come from "outside." It is an extension of their work as advisers for the AEC, and it would most likely flow through institutionalized channels and grooves. It would not be mere "opinion," but would most likely come equipped with charts, statistics, experiments, and calculations.

Ultimately, our point is not that there are no individuals who could be reasonably identified as "public intellectuals" (although never without implicit or explicit boundary work excluding others from the same status), nor do we wish to reject the use of the biographical or prosopographical method in historical analysis, nor are we suggesting that there is no point in analyzing a media "space of opinion" (Jacobs and Townsley 2012) where such individuals may possess significant symbolic capital. Our point is that the analytical problem indexed by the concept of intellectual-namely, the problem of how knowledge is mobilized to influence public affairs-is better served by broadening the analytical lens to include not only prominent individuals but also gray practitioners and collectives (hence even biographies of prominent intellectuals must be analyzed in the context of a whole field of competing and interdependent agencies); not only op-eds and "ideas" but also technical means of shaping, representing, and intervening in public affairs (hence no prosopography of an "epistemic community" is complete without examining the devices and networks it mobilizes or takes apart as part of its advocacy); not only the mediatized sphere of opinion but also the multiple "ports into the Leviathan" established by specific types of expertise. All these considerations, we argue, are doubly relevant when it comes to economists and the question of how economic expertise is mobilized to influence public affairs.

\section{Why Thinking in Terms of Interventions Is Especially Suited for Analyzing the Public Impact of Economists and Economic Expertise}

We organize our comments here through the trio of agencies, modes, and targets of intervention. 
There are, no doubt, a few prominent economists who enjoy media celebrity and opine about public affairs from the pages of the New York Times or in best seller books, but they are the exception. The self-perception of economists is as technical experts, and many wield public influence not as intellectuals but as advisers, "chief economists" of firms and banks, technocrats, and technical innovators. Moreover, by its very nature, the work of economic calculation is collaborative and requires academic or government economists to join forces with "economists in the wild" (Callon 1998), such as accountants, statisticians, risk analysts, and so on. In short, economics by its very nature entails multiple and varied agencies of intervention.

Some economists, no doubt, write op-eds, as do many other academics (Jacobs and Townsley 2012), but to limit analytical attention to this mode of intervention is to lose sight of what is most distinctive about economic expertise and how it is inserted into the public sphere through formulas, charts, accounting conventions, index numbers, and so on. In recent years, this point has been made most forcefully by the "performativity" school. To say that economics is performative is to argue that it does not describe or explain the economy from outside but weaves a network that reaches all the way from the citadels of academia through "economists in the wild," to the economic actors themselves, equipping them with calculative prostheses on which they rely in making decisions (Callon 1998). This argument, as we shall see, is in surprising agreement with Wesley Mitchell's and Irving Fisher's respective visions for how the index numbers and statistical aggregates they produced were expected to affect economic reality (Breslau 2003, 405). Performativity, therefore, has the double sense of (1) giving form, pre-forming; the waffle does not exist independently of the waffle iron, and things economic-as distinct from what is considered "noneconomic" - do not exist independently of the grid of knowledge that disentangles and frames them so they become calculable (see also Eyal 2012); and (2) but to perform is also to act, to intervene; the statements of economics are not descriptions, they are ways of "doing things with numbers" (to paraphrase the British philosopher J. L. Austin). The relationship between economic knowledge and economic reality is not one of description or explanation but, as Daniel Breslau (2011) puts it, "applied Platonism." When economists are consulted about the design of electricity markets, for example, they compare existing markets with the "platonic" model of perfect market competition and ask what institutional arrangements and/or calculative devices would permit these markets to approximate the functioning of the ideal model. The model itself is not modified 
by the contrast with reality, but on the contrary, reality is modified to approximate the model by equipping economic actors with the means and motivations to calculate as if they inhabit the virtual terrain of perfect competition. Similarly, the Black-Sholes formula is not a representation of existing reality but a tool used to price an option within given limitations of information (i.e., it disentangles the option so that calculation is possible), so that the behavior of market actors can approximate the model of perfect competition (MacKenzie 2007; MacKenzie and Milo 2003). I do not think, however, that the argument of "performativity" rests on whether the introduction of calculative devices and/or institutional arrangements modifies economic processes in a way that confirms or disconfirms the economic theory from which they derive (what MacKenzie [2007] calls "Barnesian performativity" and "counter-performativity," respectively). A tool may be "right for the job" or not. It may do the job well or sloppily. But we do not say that the tool has been confirmed or disconfirmed. The performativity of economics rests on the fact that its concepts and formulas are used as tools to shape the behavior of economic actors. The tools are measured not by their "truth" (which belongs to the Platonic realm of the ideal model) but by their relative ability to bring about the closest possible approximation to the desirable output of the ideal model, namely, governability-orderly coordination of the autonomous activities of multiple calculative agencies, predictability, self-correction, responsiveness to the "light hand" of a governor who modifies incentives only gradually and piecemeal. So most of the time economists intervene in public affairs not by writing or commenting to a general audience but through a far more "technical" mode of intervention, namely, by equipping economic actors and governors with calculative tools designed to bring about governability, or by taking apart such calculative devices to expose the assumptions about public affairs built into them. The case of index numbers - the topic of the next section-is a good example of this mode of intervention.

Moreover, even when economists do write or comment to a general audience, it is not always insightful to think of them as public intellectuals. The idea of public intellectuals assumes that speech is meant to inform, educate, influence, and persuade. As noted earlier, it is intimately tied to the concept of opinion. But is this really the best way to construe, let us say, what Ben Bernanke has to say about the economy, whether in a press conference, a carefully worded Fed dispatch, or even an op-ed piece? (McGregor and Young, this volume). Speaking or writing in these cases has a completely different value than "opinion." It is not description or even prescription but action, a policy tool. It is part of a game in which 
the audience construes what is said as intended to signal certain intentions or actions on the part of the Fed. So the statements are prepared in advance by Fed policymakers reflecting how they expect the audience will construe each and every specific expression, qualifier, adjective, or number. Of course, this process of careful preparation and calibration is something of which the audience is well aware and takes into its interpretation, which means that the drafting has to take into account this double hermeneutic layer, and so on and so forth. The same goes for the "chief economists" of large banks, who are regularly interviewed in the press to give their opinion or assessment of the state of the economy. They, too, calculate in advance what they say because they know that a crowd of investors and brokers is listening to the very "tone" of their message, and like good economists they are well aware of all the unintended and perverse consequences that can follow. Economics may be highly mathematized; it may even claim to have absorbed the mathematics of information and communication games (Mirowski 2002); but at the core of its form of expertise there is also a fairly imprecise and nonmathematical language game. Its tool kit, especially for "economists in the wild," is chock-full of flowery adjectives that would make a wine critic blush (as in speaking of a "soft" market or a "sluggish" recovery), and it is characterized by special attention to how things can be done by words, and how to keep the audience continually guessing. This sort of speech is snake-charming the economy. It is certainly a form of public intervention of sorts. But even when it appears on the op-ed page of the New York Times it is not "opinion," not the public intellectual speech variant.

Finally, most of the time the target of economists' interventions is not the open, homogeneous sphere of public opinion but the multiple frail conduits by which economic expertise is linked with politics and the state, the multiple institutional arenas where economic things become public. In the next section, we pay close attention to how one such institutional arenathe system of national accounts-emerged, and what types of public intervention become possible along this conduit. The general point is that economic expertise is not something that is formulated in the academy and then "applied" elsewhere. It is a network that stretches from the academy through businesses and quasi-governmental organizations, along a permanent "port" into the state. The largest employer for new US economics $\mathrm{PhDs}$ is the US government (18 percent in 1997), followed by the International Monetary Fund, World Bank, and the Federal Reserve. The only discipline better represented in government is physics (Siegfried and Stock 1999). More importantly, economic expertise is absolutely essential to how 
modern, liberal societies are governed (Miller and Rose 1990). "Economy" originally meant the correct manner of governing individuals, goods, and wealth, and "political economy" was concerned with how to introduce this economy (frugality, rationality, calculability) into the general running of the state (Foucault 1991, 92). Even when economics are seemingly technical and neutral, they are often about a problem of government broadly understood, namely, about the art of governing people, things, and relations and leading them toward a convenient end-equitable distribution, efficiency, growth, and so on. Economists, therefore, are different from most other experts. Whether or not they are employed by the state, economists' technical field of expertise is never very far from politics and the public sphere, because it is about how to arrange things, relations, incentives, and rules so as to produce governability, and because liberal states govern by means of calculation. The more technical economists' work is, the more it is about "governing by numbers" (Desrosières 2008; Miller 2004; Porter 1995). So our point is that most economists, most of the time, intervene not in the public sphere of opinion but through the multiple arenas where economic expertise intersects with the state and where numbers are produced through which liberal societies are governed.

Once again, our point is not to argue that there are no prominent economists who write or speak about public affairs in the mediatized public sphere, but that the analytic question about how economic expertise intervenes in public affairs should not be reduced to this rather narrow view. Moreover, comparative work on the economics profession (Fourcade 2009) demonstrates that the extent to which the public stance of economists corresponds to this image of the "public intellectual" is highly variable and dependent on specific institutional constellations, on the relations between the state, business, the academy, and the media, and the political cultures of expertise to which they gave rise. To be an economist and to intervene in public affairs means something quite different if you are an American, French, or British economist. The "centrality of market institutions to US political culture" and the consequent "definition of the economist by a technical, measurable form of competence" has meant that American economists intervene in the public sphere primarily by producing a "vast array of practical instruments that are widely used in policy and business" or by mobilizing economic knowledge as a "marketable political commodity that helps different groups with public claims fight one another" (8-9). French economists, in contrast, are shaped by a "national political culture and institutional makeup centered on the administrative exercise of public power" wherein they play the role of technocrats, and where economic 
knowledge is produced directly as part of the formulation of state policy, so economists intervene in public affairs by formulating policy, for example, by working for the Commissariat général du plan (11). In the United Kingdom, finally, a "political culture centered on small, tightly knit elite societies that traditionally enjoy great authority in producing public discourse" meant that a greater premium was placed on the "ability to communicate economic ideas in plain and eloquent language" through both interpersonal networks as well as writing directly to the general, educated public (9-11). Put differently, if British economists tend to fit more the image of the "public intellectual" as the engaged man of letters (as is evident in the essay on John Maynard Keynes by Roger Backhouse and Bradley Bateman, and the essay on Lionel Robbins by Susan Howson, both in this volume), this is because of the specific constellation connecting Oxbridge with the civil service and with elite media outlets and clubs. In this restricted milieu, an audience exists for the speech variant that is closest to the image of the "public intellectual." The American case, in comparison, best approximates the format of public intervention as technical performativity we discussed earlier: the tight linkage between research departments, businesses, and regulatory agencies providing the ideal ecology for it.

This is, of course, a simplified summary of a much more complex analysis. In reality, the different formats of intervention are co-present in each national case. The bifurcation of economics in France, for example, between state technocrats and academicians leads the latter to attempt to influence state policy by writing op-ed pieces in the major newspapers, while clubs de réflexion bring together academic economists, senior civil servants, journalists, and business and union leaders, forming a horizontal network through which economic ideas can influence the governing elites (Fourcade 2009, 232-33). This merely vindicates, however, our main point, namely, that once we consider how economic knowledge is mobilized to intervene in public affairs we are confronted with a plurality not only of agencies and formats of intervention but also of public arenas or spheres where such interventions take place. Economists intervene in public affairs when they write "directly" to the public in op-ed pieces or generalist books, but also when they have the ear of business leaders and civil servants in more-rarefied forums; when they produce position papers for think tanks or are trained by these to become "talking heads"; when they become advisers or advocates or expert witnesses on behalf of consumer organizations; and also when they work for state agencies or businesses to design markets or devise economic indicators. 


\section{The GDP as an Institutionalized Interface between Economic Expertise and Statecraft}

The preparation of economic indicators and summary indexes may seem a dreary technical activity with none of the glamour associated with public intellectuals, yet it is a key form in which economic expertise intervenes in public affairs. Our example in this essay is the prodigious and, by now, four-decades-long collective attempt to provide a summary index of human welfare and economic progress that could replace, supplement, or correct the GDP. This collective attempt has recently achieved some evident success and publicity through the agency of the French government and the work of the Commission on the Measurement of Economic Performance and Social Progress (CMEPSP), headed by the economists Joseph Stiglitz, Amartya Sen, and Jean-Paul Fitoussi (2009). Yet it is important to note that the Stiglitz-Sen-Fitoussi project is but the most recent and most famous example of what had begun already in 1972 with James Tobin and William Nordhaus's work on the Measure of Economic Welfare (MEW) and was continued by a host of other economists working inside and outside academia, in nongovernmental organizations and think tanks, as well as in state economic and statistical agencies and international agencies ranging from the Organisation for Economic Co-operation and Development to the United Nations Development Programme (Afsa et al. 2009). In their report, Afsa et al. (2009) compile information on thirty extant indexes, but note that many more exist, which they could not cover.

We would like to begin, however, with a short history of the GDP itself. We argued earlier that economic expertise does not intervene in public affairs from without. It is plugged into the body of the Leviathan through various permanent ports, institutionalized interfaces between economic expertise and statecraft. The GDP, or more precisely the system of national accounts, represents such an institutionalized interface. To understand current efforts at public intervention by economists who prepare summary indexes, we first need to describe the terrain on which they take place, the quasi-public sphere that is the system of national accounts.

In a very general sense, economic indicators such as the GDP work in the same way as the Black-Scholes formula, or the other calculative devices we described under the heading of technical performativity. In a perfect market, economic actors would have perfect and complete information about economic activities and enough time to peruse and evaluate this information to arrive at the optimal investment decision. GDP, CPI, or an index of aggregate productivity trends are tools meant to equip the 
economic actor with computational proxies for the information that is lacking or cannot be evaluated within human finite time. But this analogy to performativity is incomplete and does not capture the historically specific way in which economic indicators such as the GDP developed and how they function in the public sphere.

The GDP owes its origins, in fact, to a transition from the point of view of the economic actor to that of the economic governor. The production of statistical series of economic aggregates at the National Bureau of Economic Research (NBER) began in the 1920s guided by Wesley Mitchell's theory of the business cycle. Mitchell thought that if business managers and other economic actors were equipped with these aggregate indicators as calculative devices, they would make sound investment decisions because they would take "the entire picture of the business economy in their calculations." Consequently, the business cycle would be eliminated or at least moderated (Breslau 2003, 405). Mitchell's ambition, therefore, was precisely to achieve what today is called "performativity." Economic expertise would equip business managers with index numbers so that they would be better able to calculate, better able to act as rational economic actors and thus render markets governable. But this is not how Mitchell's numbers ended up being used. Historians of the system of national accounting do not locate its origins in NBER's efforts during the 1920s but in the governmental reaction to the stock market crash of 1929 (Vanoli 2005, 16-18, 26-27). Simon Kuznets's (1934) classic estimate of total national income produced and national income paid out, to which current measures of GDP owe their provenance, was compiled in response to a request by the US Senate to estimate the extent to which the economy contracted during the Great Depression, 1929-32. The Senate directed the Department of Commerce to provide the estimate, but when it became evident that it did not have the means to do so, the request was forwarded to Mitchell at NBER, who suggested Kuznets. ${ }^{5}$ Thus the origins of the GDP are when the techniques developed at NBER were called on to equip the economic governor with the means "to see where the economy has been and ... where it is going and the kinds of policies necessary for governments, and private groups or individuals to achieve their objectives" (Kendrick 1996, 2; Kapuria-Foreman and Perlman 1995, 1541; Kenessey 1994, 12-13). Similarly, the Bureau of Economic Analysis (2000) celebrates the GDP as "one of the great inventions of the 20th century" and

5. Kuznets delegated the task to two of his best students-Robert Nathan and Milton Gilbert-both already employed by the Department of Commerce. 
speaks of it as a "beacon that help[s] policymakers steer the economy toward the key economic objectives."

The Senate wanted to know, in short, how bad the depression was, whether recovery was under way, and what else could be done. For this purpose, however, it needed more than just descriptive statistical aggregates. These had to be linked to one another as a system of causal variables within a framework that explained how they related to one another and what levers they provided for policy. Ultimately, this framework was provided by Keynes, but before Keynes-and in an important sense this provided the ground on which Keynes's theory was built-it was provided by the introduction of accounting methods and tools, especially doubleentry bookkeeping, turning economic statistics into "social accounting" (later "national accounting") and turning the statistical series into a system of controlling accounts. Kuznets drew on the work done by Irving Fisher to introduce accounting methods into economics. Thus in 1934, before the publication of the General Theory, Kuznets's empirical analysis had already begun measuring these causal variables, to which Keynes would give a more solid theoretical grounding. Theory and measurement would be adjusted to one another, says Zoltan Kenessey (1994, 112), because they responded to the same policy needs. What needs to be added is that they were also formulated from the same point of view of "social accounting," the point of view of the economic governor now conceived as the accountant balancing the books of the national economy (see also Vanoli 2005, 19).

There is a tight linkage, indeed, between the GDP, the application of accounting methods to economic analysis, Keynesianism, and the invention of the "economy" as an object of knowledge and government. As Breslau (2003, 380, 407-8) and Mitchell (1998) convincingly demonstrate, the term the economy simply did not appear in economic texts before the 1940s, certainly not in the sense given to it today as a bounded totality of economic activity abstracted from social life. The economy postdated the huge effort of compiling national statistical series of production, prices, wages, and so on, and only through this effort could it come to designate the aggregate of a nation's productive activities. An essential part of the whole exercise was to define what is considered economic activity and what is not, something that did not bother at all the earlier political economists. Kuznets and colleagues "pre-formed" the economy by disentangling what they considered obvious evidence of "participation ... in the economic activity of the nation," that is, "work for wages, profit or salary, or . . capital investment in industry" 
from what they considered to be "non-economic" activities. The most obvious of these was the exclusion of unpaid domestic work, but Kuznets and colleagues also excluded other items that previous economists have included in their own estimates, such as "imputed net rental," that is, income accruing to people living in their own homes (Kuznets 1934, 4). By the same token, however, only through the huge effort of producing the concepts and measures of "social accounting" could the "national economy" come to be understood as the object of "macroeconomics," that is, of a causal theory that treated it as a relatively bounded system of interrelated flows. The true beginnings of modern macroeconomics, said Hicks, was not the General Theory (1936) but Keynes's pamphlet How to Pay for the War (1940), which worked out a national accounting structure for the British economy (quoted in Kurabayashi 1994, 96-98), thereby specifying in measurable forms the Keynesian variables. This was the context in which the GDP or GNP finally came into being. While the term GNP was already used during the 1930s, and Kuznets's analysis certainly gestured at it, World War II provided the final impetus for the formation of a system of national accounts, and the annual measurement and publication of GDP figures, in both the United States and Britain. In both cases, the GDP and related measures were required in order to address questions touching on the war effort: How to pay for the war? How to determine the correct balance between defense and civilian spending ("guns or butter tradeoff")? How to avoid spiraling inflation at the end of war? What would be the effect of demobilization on employment? (Kurabayashi 1994, 95; Kenessey 1994, 111; Vanoli 2005, 21-23).

From this beginning, the system of national accounts evolved into an "articulated macro level statistical response to the operational demands of a Keynesian economics" (Ward 2004, 10). At the heart of later critiques of the GDP there would be precisely this point that it is not simply an objective measure of the economy but a translation of the concern with full employment and growth-central to Keynesian theory, but also intimately tied to the postwar context in the United States and the UK and to the ideological struggles of the Cold War-into a quantitative standard. The universalization of this standard by the United Nations in the 1950s thus biased economic policies in ways that were often harmful to third world countries and to substantive conceptions of human welfare (7, 63-67), a point made and bemoaned even by Kuznets himself (Kapuria-Foreman and Perlman 1995, 1532-33).

We have engaged in this rather brief history of the origins of the GDP and the system of national accounts in order to give substance to our claim 
that the system of national accounts is a public sphere of sorts, and that consequently the design of alternatives to the GDP could be analyzed as a form of intervention in public affairs. Economic indicators like the GDP are tools meant to provide decision makers with a bird's-eye view of the economy and permit them to make rational decisions, but they are also "black boxes" that obscure from view the assumptions, policy choices, and history of usage they encapsulate. Thus Keynes's $(1936,383)$ oft-quoted adage that "practical men, who believe themselves to be quite exempt from any intellectual influence, are usually the slaves of some defunct economist" is particularly apt when considering the impact of economic indicators generally, and of the GDP specifically. ${ }^{6}$ As noted above, it encapsulated within itself a Keynesian conception of macroeconomic management, a certain role for the economic governor, and a restrictive definition of human welfare and the activities contributing to it. No less importantly, the activities of compiling, calculating, and using the GDP occupy a multitude of economists both inside and outside government: to the 18 percent of new economics PhDs being employed in government (Siegfried and Stock 1999), we would add a probably equal proportion of new PhDs employed in the private sector whose concrete working activities would consist primarily of perusing daily the indicators and tables produced by the system of national accounts, and another large proportion of academic economists who use these as the primary data for their research. The activities of compiling, calculating, and using the GDP thus constitute a permanent port through which economic expertise is constantly brought to bear on some of the most central issues in the public sphere-how to define and measure the public good, or human welfare - that the state is entrusted with protecting and increasing. Once this port exists, it becomes possible,

6. A good example is the indicator of aggregate productivity trends. As Fred Block and Gene Burns (1986) show, it was compiled as part of an underconsumptionist explanation for the Great Depression. Productivity gains, it was argued, would lead to weakening demand if wages do not rise as fast, or prices decline accordingly. Then, through the efforts of the Department of Labor, a specific version of the indicator became institutionalized as the linchpin in the post-World War II bargain between organized labor and big corporations. The indicator thus encapsulated within itself a theory not only of economic processes but no less importantly of the "subject" of government, if you will: namely, a conception of the proper role of the economic governor in steering and stabilizing the economy, encapsulated in the wage and price guidelines issued by the Council of Economic Advisers during the Kennedy administration. When the indicator begun showing declines in aggregate productivity in the late 1960s, this "fact" framed political debates and empowered wage restraint policies, even though, as Block and Burns show, slightly different versions of the indicator would have produced dramatically different trends. Decision makers were the "slaves" of the defunct economists who constructed the specific version of the indicator and of the underconsumptionist theory encapsulated in it. 
and indeed inescapable, to intervene in public affairs by changing some aspects of the economic expertise flowing through it. No surprise, then, that seemingly technical and abstruse debates about how to calculate the GDP can involve quite vehement disputes, reflect policy disagreements, pitting one against the other divergent political ideologies and the interests of nation-states (Popkin 2000; Lower 1990; Ward 2004, 64-67; Aukurst 1994, 43).

\section{Alternatives to the GDP as Public Interventions}

"Economists all know," declared Nordhaus and Tobin (1972, 4), that "maximization of GNP is not a proper objective of policy . . and yet their everyday use of GNP as the standard measure of economic performance apparently conveys the impression that they are evangelistic worshipers of GNP." To correct this impression and to respond to the "limits to growth" critics, they constructed a Measure of Economic Welfare (MEW) that was largely a rearrangement of the items of the national accounts so that what it measured was not output but household consumption (5). They used this measure to reply to the critics of growthoriented policies-since the MEW grew at a rate only slightly below the GNP. Growth is not obsolete, they declared: "The broad picture of secular progress which the [GNP and similar measures] convey remains after correction of their most obvious deficiencies" (24). This essentially conservative move, however, became the first salvo in a much longer offensive that consistently tracked the two issues tackled by Tobin and Nordhaus, namely, the irrelevance of output measures for estimating human welfare and the problem of sustainability (4). Why is it that a relatively conservative or defensive position in the public debate about limits to growth has become the forerunner of a much more radical effort-as we show below-to revise economic priorities, an effort that now counts Tobin and Nordhaus as its founding fathers in its retrospective histories? The answer is obvious. It has nothing to do with what Tobin and Nordhaus said, but with how they said it. What mattered to those who followed in their footsteps was the fact that Tobin and Nordhaus showed, from within NBER, that it is possible to construct an alternative number. What counted most, what was innovative, was the mode of intervention in public affairs, not the specific position they took in the debate.

Tobin and Nordhaus opened the floodgates. In the years immediately following there were several attempts to produce an alternative index of 
welfare, one that would show-contra Tobin and Nordhaus-that growth as measured by the GDP was increasingly irrelevant to the more fundamental goal of human welfare. Among these were the Japanese Net National Welfare (NNW) indicator in 1973, the Economic Aspects of Welfare (EAW) index (Zolatas 1981), the Physical Quality of Life Index (PQLI) (Overseas Development Council 1980), and the Index of Sustainable Economic Welfare (ISEW) (Daly and Cobb 1989), which later became the Genuine Progress Indicator (GPI) (Talberth, Cobb, and Slattery 2007). By far the most successful and influential of these, however, is the Human Development Index (HDI) produced by the United Nations Development Programme (UNDP) from 1990 onward.

The story of how the HDI came about is told by Frederick Wherry (2004, 161). The main driving force behind the HDI was Mahbub ul Haq, a British-trained Pakistani economist who worked at the World Bank (1970-82), served as Pakistan's minister of planning and finance (198288), and then was drafted as special adviser to the UNDP (1989-96). Haq-a close personal friend of Amartya K. Sen, later winner of the Nobel Prize in economics-wanted "to shift the focus of development economics from national income accounting to people centered policies" (Fukuda-Parr 2003, 303, 305). That is, he wanted to intervene in public affairs and set a new agenda of policy priorities.

Haq, however, did not create the HDI by himself. Compiling the HDI was collective work by the Human Development Report Team with a staff of five statisticians and economists, and a much larger group of consultants drawn from the Society for International Development (SID), an international nonprofit acting as knowledge broker to foster sustainable development. Sen was the most famous of these consultants, but all the others were also highly respected economists and development professionals (Wherry 2004, 161). Today, the Human Development Report Team consists of eighteen regular staff members who are statisticians, economists, MBAs as well as one anthropologist. ${ }^{7}$

Even though the team was assembled under the auspices of the UNDP, an administrative unit of the UN, it cultivated a measure of social, physical, and administrative distance from it. Wherry (2004, 163-64) shows quite convincingly that the initial Human Development Report Team that first compiled the HDI enjoyed a semi-outsider status that permitted it to

7. See the list of team members, along with links to capsule biographies of each member, at hdr.undp.org/en/contacts/about/ (accessed November 8, 2012). 
act independently to reshape the agenda of development discourse and policy. The consultants and the staff were newly recruited to the UN and knew each other from SID. As one of them recollected, the team "wasn't a UNDP or a UN thing ... it was very outside of the UN, [and it was] full of a lot of people who are not accountable to the UN." The team occupied offices physically separate from UNDP and enjoyed a protective umbrella supplied by the chief administrator of the UNDP, Bill Draper, a former venture capitalist. In this sense, the initial team with its consultants was more akin to an "epistemic community" than a bureaucracy.

This semiseparation at the institutional and personnel level was balanced by continuity at the level of the actual product of the group's work. The Human Development Report and the HDI were crafted so they bore "strong family resemblance" to the World Bank's World Development Report, and also to the GNP. On this latter issue there was dissension within the group. Sen and others were concerned that the full complexity of human capabilities could not be captured in a single index, but Haq responded to their doubts by insisting that "only a single number could shift the attention of policy-makers from material output to human wellbeing as a real measure of progress." He argued emphatically that "we need a measure ... of the same level of vulgarity as the GNP-just one number-but a measure that is not as blind to the social aspect of human lives as the GNP is." And "vulgar," or simplistic, indeed it is. The HDI is a composite weighted index combining scores for economic growth (GDP), health (life expectancy at birth), and education (adult literacy rate and student enrollment rates). It thus captures a very general notion of "welfare" as material well-being and of "capabilities" as being healthy and educated. Despite Sen's doubts, Haq was convinced that a single, composite index number would be much more effective than the written reports in "convincing the public, academics, and policy-makers that they should evaluate development by advances in human well-being and not only by advances in the economy" (Wherry 2004, 165-66; Fukuda-Parr 2003, 303, 305). Put differently, Haq's judgment was that in order to achieve the public aims of Sen's intellectual work, the format of intervention had to be changed from one that corresponded to the classical image of the public intellectual (which Sen embodies to great effect) to the different format of an index number, however simplistic and "vulgar," ultimately because it can be plugged into already existing institutions and networks of policymaking.

If the classic public intellectual is an outsider, a prophet, Haq and the Human Development Report team positioned themselves as insiders/out- 
siders, structurally equivalent to what Georg Simmel (1950) identified as the position of the "stranger." We think this sort of insider-outsider status is typical of "specific intellectuals" and in fact illustrates our point that intervention happens through an established port or interface. Wherry (2004, 164) comments insightfully that this "insider-outsider" status is what permitted the team to formulate the HDI as a bold departure from business as usual-because they were independent of the administrative routines and political pressures of the UN-yet, also as a highly effective intervention in development discourse and policy, because they acted under the auspices of UNDP and enjoyed the legitimacy, resources, and attention it commanded. If they had been either insiders (bureaucrats) or outsiders (public intellectuals), they would not have been able to craft this effective intervention in public affairs. It was the movement of bringing the outsiders in, and the insiders out, along preexisting conduits represented by SID and by the system of national accounts that explains the HDI's success as public intervention.

And success (or notoriety) it did enjoy. The first report in 1990 provoked a firestorm of criticism (and attention) precisely because of the table comparing where countries ranked on the HDI-the United States, second in GNP per capita, fell to nineteenth behind most of the advanced industrialized countries, while Cuba shot up forty-four places higher than where it ranked by GNP. Yet the report and the index were adopted by the UN and were plugged into its normal operations. By 2000, the UNDP was printing one hundred thousand copies of the report in ten different languages for distribution. Many national governments now produce their own "human development" report, in hopes of improving their ranking (Wherry 2004, 153, 166-67). The assessment of many observers is that the HDI managed to change public discourse about development, shifting it from being centered on growth and bringing attention to other dimensions of development. It was an effective intervention in public affairs.

However successful, the HDI was also deeply flawed. Its measurement of welfare was crude, failing to account for income distribution, subjective dimensions of welfare, and the critical literature pointing to the importance of nonmarket services (Waring 1988), and it did not touch at all on the matter of sustainability. Hence its publication merely led to even more new indexes. Information about a few representative examples is summarized in table 1 . A few points regarding the agencies, modes, and targets of intervention are noteworthy.

The first point is that the work of constructing and deconstructing economic indicators, as reflected in HDI and these later indicators, is 


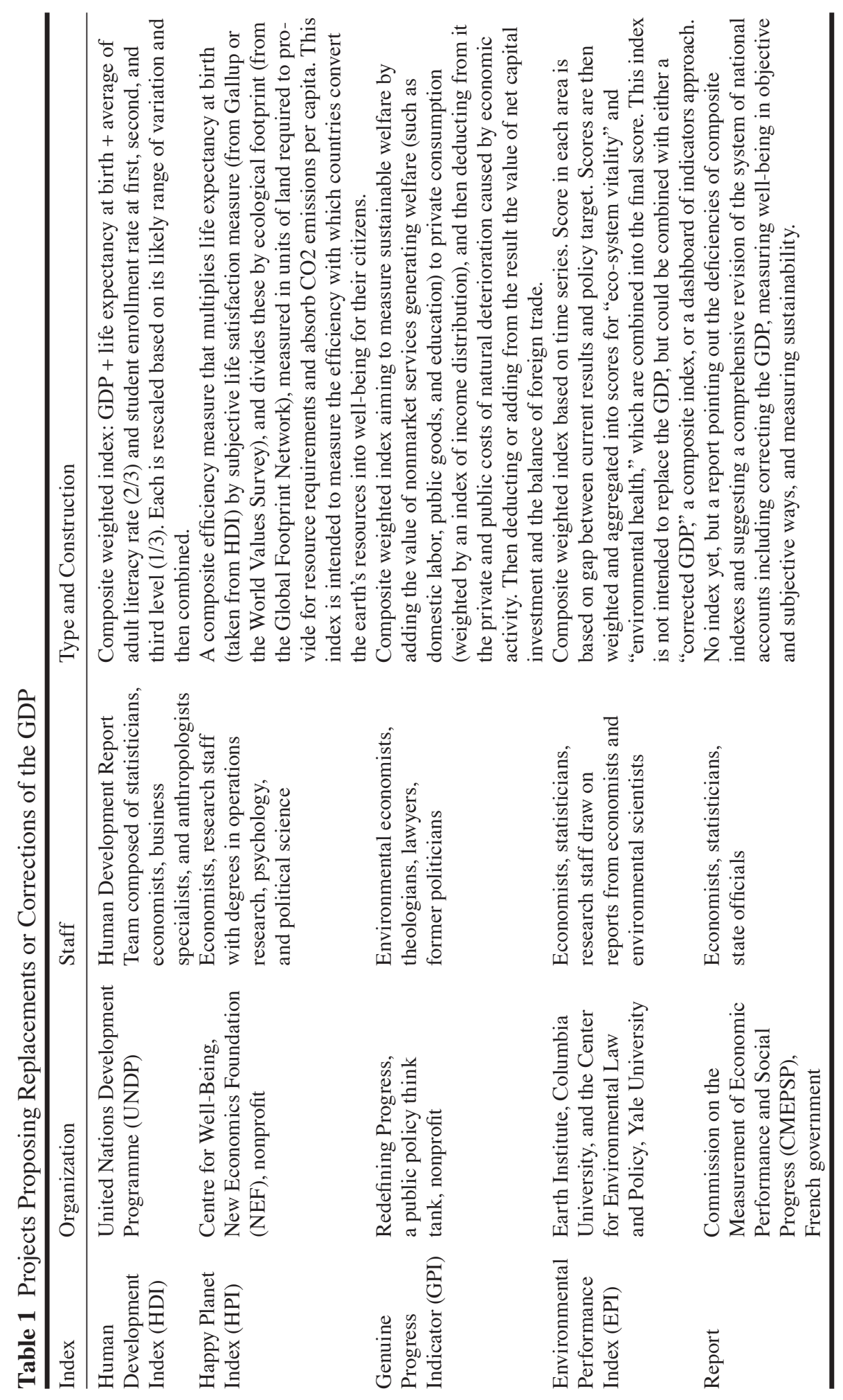


collective, interdisciplinary, and long-term. Stiglitz, Sen, and Fitoussi provide the intellectual glamour and public face of the CMEPSP, but there are twenty-two other economists and social scientists on the commission, including Kenneth Arrow, Kemal Dervis, Daniel Kahneman, and Robert Putnam. More importantly, a team of nine Rapporteurs consisting of leading French statisticians and economists provides much of the deeper analysis on which the work of this commission relies (Stiglitz, Sen, and Fitoussi 2009). And if the work of the commission, which for the moment culminated merely in a report and recommendations, were to be translated into a revision of the system of national accounts, a new synthetic index and a "dashboard" of additional relevant indicators as foreseen, it would surely take a small army of not only junior economists and statisticians but also environmental scientists, policy analysts, psychologists, sociologists, and the all-important accountants to compile it. Similarly, the Happy Planet Index (HPI), which purports to measure "the relative efficiency with which nations convert the planet's natural resources into long and happy lives for their citizens," is compiled at the Centre for Well-Being at the New Economics Foundation (NEF), by a large team of fellows and researchers with backgrounds in economics, operations research, experimental psychology, political science, and so on. ${ }^{8}$ The Genuine Progress Indicator (GPI) is a composite index developed on the basis of the earlier ISEW. It is compiled by a team of economists and environmental experts at Redefining Progress, a public policy think tank in Oakland, California. ${ }^{9}$ The Environmental Performance Index (EPI) - "a composite index tracking a diverse set of socioeconomic, environmental, and institutional indicators that characterize and influence environmental sustainability at the national scale"-is compiled jointly by the Earth Institute at Columbia University and the Center for Environmental Law and Policy at Yale University. A core team of five investigators draws on several dozen expert contributors, some of whom are economists and many are environmental scientists..$^{10}$ In short, the production of indexes and economic indicators is the work of collectives composed of a large number of individuals representing different disciplines, forms of expertise, and institutional affiliations.

8. For more on the Happy Planet Index, visit its website at www.happyplanetindex.org/ (accessed November 8, 2012).

9. For more on Redesigning Progress, visit its website at rprogress.org/index.htm (accessed November 8, 2012).

10. The 2012 report of the EPI can be found at epi.yale.edu/sites/default/files/downloads/2012-epi-full-report.pdf (accessed November 8, 2012). 
The second point is about the format of public intervention in these examples, which is not an op-ed, a petition, a book, or a blog, but typically a number. Granted, the number is usually surrounded by a whole lot of words: programmatic launch statements, "discussion," technical clarifications, and so on, but ultimately the whole endeavor of producing summary index numbers would not make sense if the participants did not believe that, so to speak, a single number is worth a thousand words. Unlike HDI, the numbers now incorporate a measure of sustainability. The GPI incorporates the estimated costs of air pollution and destruction of the natural environment. The HPI measures the ecological efficiency with which well-being is provided by incorporating a measure of "ecological footprint" in the denominator. The EPI measures the degree to which a country is moving toward the policy goals of environmental health and ecosystem vitality.

The exception that proves the rule is the report coauthored by Stiglitz, Sen, and Fitoussi. They explicitly reject the idea that their target should be a single index number. There is a sense that this report, coming two decades after the HDI, now marks the end of an era. As noted earlier, the French team compiled information on thirty extant indexes, but noted that many more exist (Afsa et al. 2009). In such a saturated field, it is perhaps no longer a meaningful intervention to produce one more number, one more acronym, which most likely will disappear among the many similar sounding indexes, or at best would be incorporated like the HDI alongside the GDP, but only as supporting cast. Instead, Stiglitz, Sen, and Fitoussi (2009) did two things. First, they compiled an exhaustive and critical review of all extant indexes, including the GDP, and the different approaches taken in compiling them. Pointing out the deficiencies, they argue for the need to create a new international system of national accounts capable of calculating a corrected measure for GDP (which would include nonmarket services), objective and subjective measures of well-being, and a measure of sustainability. Put differently, their report opens up the "black boxes" of which economic indicators, both mainstream and alternative ones, are made, pillages their components, and proposes a new set of accounts that would pre-form "the economy" in a different way. This new system of national accounts would define, for later decision makers, not only the facts on which they base their calculations but also their own proper role as governors of economic life. This is exactly what is being attempted also by the other three measures surveyed here, although in more piecemeal fashion. The task of the economic gov- 
ernor, they argue, is not to maximize growth but to maximize sustainable welfare and well-being, and to achieve this goal the government needs an appropriate index-indeed, a whole new system of national accounts that brings into calculation what were previously deemed incalculable externalities.

The third point is about the target of intervention common to these projects. To our mind, they all are built around a similar inside-outside movement as we saw with the HDI. It is true that the GPI, HPI, and EPI are produced by either independent nonprofit organizations (essentially, think tanks) or university institutes, and thus they exhibit a measure of independence and distance from national or international bureaucracies. At the same time, however, they seek to plug their indexes into the existing ports or conduits through which economic expertise flows into the state, and therefore they cultivate social ties that facilitate this plug-in. Redefining Progress, where the GPI is calculated, although it was begun by a renegade environmental economist and a theologian, is now a respected public policy think tank, with a former Republican congressman as executive director, a host of corporate funders, and former managers from PG\&E, Apple, and other corporations on its board of directors. ${ }^{11}$ It has offered its GPI as a "guide for public policy" and had some success persuading the state of Maryland to adopt it. ${ }^{12}$ An affiliated think tank, GPIAtlantic, has taken up the same cause in Nova Scotia, Canada, and provides regional government there with policy briefs as well as with a comprehensive system of Nova Scotia GPI Accounts (Pannozzo and Colman 2009).

The New Economics Foundation (NEF), where HPI is produced, characterizes itself as a "think and do tank" that is in the business of "promoting innovative solutions that challenge mainstream thinking on economic, environment and social issues." It is one of the biggest think tanks in the UK with a permanent staff of fifty and a continuous set of activities apart from compiling the GPI, including advocacy among

11. Our information regarding Redefining Progress comes from Source Watch, which is published by the Center for Media and Democracy and can be found at www.sourcewatch. org/index.php?title=Redefining_Progress (accessed November 8, 2012). According to the website of the Center for Media and Democracy, Source Watch is a "collaborative resource for citizens and journalists looking for documented information about the corporations, industries, and people trying to influence public policy and public opinion" (www.sourcewatch.org/index.php/SourceWatch).

12. See the description of Maryland's GPI at www.green.maryland.gov/mdgpi/ (accessed November 8, 2012). 
members of Parliament and seeding other grassroots organizations such as Jubilee 2000, the Ethical Trading Initiative, and so on. While it targets some of its campaigns to policymakers, it operates at a much more populist and grassroots level than Redefining Progress. When HPI was first constructed in 2006, the report was published on the Web, and NEF proudly reports that within two days it was downloaded by a million users in 185 countries. The whole initiative to form NEF came out of The Other Economic Summit (TOES), which challenged "the right of the G7 leaders to speak for the economic future of the planet." It was supposed to be a permanent economic secretariat for TOES, but evolved into something much more far-ranging. NEF emphasizes that its proposals are often designed and run in participation with "local people" and that it "work[s] with all sections of society in the UK and internationally-civil society, government, individuals, businesses and academia."13

The Earth Institute at Columbia University, which partners with the Yale Center for Environmental Law and Policy to calculate the EPI, is not your garden-variety academic institute. It is led by one of the best-known and better politically connected US economists, Jeffrey Sachs. It is a mammoth enterprise comprising thirty centers and a staff of 850. Earth Institute experts advise national governments and the United Nations on issues related to sustainable development, combining expertise in economics with basic science and advocacy. Its advisory board includes economic luminaries such as Kenneth Arrow, celebrities such as Bono, and financiers such as George Soros. ${ }^{14}$ In short, while it is physically located at a university, and while its activities center on an academic core, it is best analyzed as inhabiting an interface between academia, government, business, and the media, as do other think tanks (Medvetz 2012).

CMEPSP, of course, differs from these three organizations by being conducted officially under the auspices of the French government, but it is plain that it enjoys a similar insider-outsider status as did the HDI team. The involvement of the French president served, in fact, to buffer the initiative from bureaucratic pressures, and the intellectual glamour commanded by Stiglitz, Sen, and Fitoussi did the rest. The report identifies its audience as composed of political leaders and relevant policymakers, who

13. www.happyplanetindex.org/about (accessed March 22, 2013). A history of NEF can be found on the organization's website at www.neweconomics.org/content/history-nef (accessed November 8, 2012).

14. For a complete list of its advisory board members, see earth.columbia.edu/articles/ view/1006 (accessed November 8, 2012). 
use the indicators to formulate policies, as well as the academic community and the national statistical offices, and only lastly civil society organizations to the extent that they are producers and users of statistics (Stiglitz, Sen, and Fitoussi 2009).

It is clear from the emphasis on doing, on solutions, on policymakers, on the users of statistics, and on working with local people, that the target of intervention is not opinion but a semitechnical, semipolitical network into which these organizations aim to plug their indicator. Or more precisely, some of these organizations indeed pay a good deal of attention to mobilizing and shaping opinion. NEF has a charter that supporters can sign online. NEF, Redefining Progress, and the Earth Institute all employ communications and public affairs staff who work to guarantee media space and attention to the research staff. Many on their staff write blogs and op-eds. But compared with the effort to have the GPI, HPI, or EPI adopted as a basis for analysis and policy, this work at the level of opinion is the least original and least important aspect of their intervention in public affairs. Some of these organizations identify themselves as belonging to a burgeoning new field of "green economics," understood as an alternative to neoclassical or mainstream economics. Green economics are, quite plainly, neither a purely academic pursuit nor pure advocacy or opinion but a technical network of experts, organizations, and calculative devices that extends along the same conduit or port by which economic expertise is plugged into the state, namely, the system of national accounts. This network typically uses as its input government data and components from the system of national accounts, and its output as well is meant to plug back into government policy in the form of index numbers, policy position papers, and, most ambitiously with CMEPSP, a complete overhaul of the system of national accounts to reflect a new epistemic and moral agenda. Taken as a whole, this network definitely fits Peter Haas's (1992, 3) concept of "epistemic community," namely, a far-flung network of "professionals with recognized expertise and competence in a particular domain and an authoritative claim to policyrelevant knowledge within that domain or issue area," who are tied together by shared truth claims and a public moral stance (see also Adler and Haas 1992; Keck and Sikkink 1998; King 2005). In this field at least, this network or epistemic community is a far more effective "collective intellectual" than public intellectuals addressing public opinion, as it gradually has been changing not only the agenda of public policy but its very infrastructure. 


\section{References}

Adler, E., and P. M. Haas. 1992. "Conclusion: Epistemic Communities, World Order, and the Creation of a Reflective Research Program." International Organization 46 (1): 367-90.

Afsa, Cédric, et al. 2009. "Survey of Existing Approaches to Measuring Socio-economic Progress." Commission on the Measurement of Economic Performance and Social Progress. www.stiglitz-sen-fitoussi.fr.

Alonso, William, and Paul Star. 1987. The Politics of Numbers. New York: Sage Foundation.

Aukurst, Odd. 1994. "The Scandinavian Contribution to National Accounting.” In Kenessey 1994, 16-65.

Bauman, Zygmunt. 1987. Legislators and Interpreters: On Modernity, Post-modernity, and Intellectuals. Cambridge: Polity.

Bell, Daniel. 1960. The End of Ideology. Glencoe, Ill.: Free Press.

Benda, J. (1927) 1928. The Treason of the Intellectuals. New York: William Morrow. Berkowitz, Nitza. 1996. "On 'The Homemaker and National Accounting." [In Hebrew.] Theoria ve-Bikoret 9:189-97.

Binkley, Robert C. 1928. "The Concept of Public Opinion in the Social Sciences." Social Forces 6 (3): 389-96.

Block, Fred, and Gene A. Burns. 1986. "Productivity as a Social Problem: The Uses and Misuses of Social Indicators." American Sociological Review 51 (6): 767-80.

Bourdieu, Pierre. (1992) 1996. "For a Corporatism of the Universal." In The Rules of Art: Genesis and Structure of the Literary Field, 337-48. Stanford: Stanford University Press.

Breslau, Daniel. 1998. In Search of the Unequivocal: The Political Economy of Measurement in US Labor Market Policy. London: Praeger.

- 2003. "Economics Invents the Economy: Mathematics, Statistics, and Models in the Work of Irving Fisher and Wesley Mitchell." Theory and Society 32 (3): 379-411.

— 2011. "What Do Market Designers Do When They Design Markets? Economists as Consultants to the Redesign of Wholesale Electricity Markets in the US." In Social Knowledge in the Making, edited by Charles Camic, Neil Gross, and Michele Lamont, 379-404. Chicago: University of Chicago Press.

Bruce-Briggs, B., ed. 1979. The New Class? New York: McGraw Hill.

Bureau of Economic Analysis. 2000. "GDP: One of the Great Inventions of the 20th Century." Survey of Current Business, January. www.bea.gov/scb/account _articles/general/0100od/maintext.htm.

Callon, Michel. 1998. "Introduction: The Embeddedness of Economic Markets in Economics." In The Laws of the Markets, edited by Michel Callon, 1-57. Oxford: Blackwell.

Daly, H., and J. Cobb. 1989. For the Common Good. Boston: Beacon.

Desrosières, Alain. 2008. Gouverner par les nombres. Paris: Presses Des Mines, Paristech.

Dewey, J. 1927. The Public and Its Problems. Athens: Ohio University Press. 
Donatich, J. 2001. "The Future of the Public Intellectual: A Forum.” Nation, February 12, 25-35, www.thenation.com/doc/20010212/forum.

Eyal, Gil. 2012. "Spaces between Fields." In Pierre Bourdieu and Historical Analysis, edited by Phil Gorski, 158-82. Durham, N.C.: Duke University Press.

Eyal, Gil, and Larissa Buchholz. 2010. "From the Sociology of Intellectuals to the Sociology of Interventions." Annual Review of Sociology 36:117-37.

Folbre, Nancy. 1989. "Women's Work and Women's Households: Gender Bias in the US Census." Social Research 56 (3): 545-69.

Foucault, Michel. 1991. "Governmentality.” In The Foucault Effect: Studies in Governmentality, edited by G. Burchell, C. Gordon, and P. Miller. Chicago: University of Chicago Press.

—. 2000. "Truth and Power." In Power, vol. 3 of Essential Works of Michel Foucault, edited by P. Rabinow and J. D. Faubion, 111-33. New York: New Press.

Fourcade, Marion. 2009. Economists and Societies. Princeton: Princeton University Press.

Fukuda-Parr, Sakiko. 2003. "The Human Development Paradigm: Operationalizing Sen's Ideas on Capabilities.” Feminist Economics 9 (2-3): 301-17.

Fuller, S. 2004. "Intellectuals: An Endangered Species in the Twenty-First Century?" Economy and Society 33:463-83.

Gieryn, T. F. 1999. Cultural Boundaries of Science: Credibility on the Line. Chicago: University of Chicago Press.

Gouldner, Alvin W. 1975-76. "Prologue to a Theory of Revolutionary Intellectuals." Telos 26:3-36.

- 1979. The Future of Intellectuals and the Rise of the New Class. New York: Seabury.

Haas, P. M. 1992. "Introduction: Epistemic Communities and International Policy." International Organization 46 (1): 1-35.

Habermas, Jürgen. 1970. “Technology and Science as Ideology.” In Towards a Rational Society, 81-127. Boston: Beacon.

Jacobs, Ronald, and Eleanor Townsley. 2012. The Space of Opinion: Media Intellectuals and the Public Sphere. Oxford: Oxford University Press.

Jacoby, Russell. 1987. The Last Intellectuals. New York: Basic Books.

Kapuria-Foreman, Vibha, and Mark Perlman. 1995. “An Economic Historian's Economist: Remembering Simon Kuznets.” Economic Journal 105 (433): 1524-47.

Keck, M., and K. Sikkink. 1998. Activists beyond Borders: Advocacy Networks in International Politics. Ithaca: Cornell University Press.

Kellner, D. 1997. "Intellectuals, the New Public Spheres, and Techno-politics. New Political Science 41-42:169-88.

Kendrick, John W. 1996. The New System of National Accounts. Dordrecht: Kluwer.

Kenessey, Zoltan. 1994. The Accounts of Nations. Amsterdam: IOS Press.

Keynes, J. M. 1936. The General Theory of Employment, Interest, and Money. London: Macmillan.

King, M. R. 2005. "Epistemic Communities and the Diffusion of Ideas: Central Bank Reform in the United Kingdom.” West European Politics 28 (1): 94-123. 
Konrad, G., and Ivan Szelenyi. 1979. The Intellectuals on the Road to Class Power. New York: Harcourt Brace Jovanovich.

Kurabayashi, Yoshimasa. 1994. "Keynes' How to Pay for the War and Its Influence on Postwar National Accounting." In Kenessey 1994, 93-108.

Kuznets, Simon. 1934. "National Income, 1929-1932." National Bureau of Economic Research Bulletin, no. 49 (June 7): 1-12.

Latour, Bruno. 1987. Science in Action: How to Follow Scientists and Engineers through Society. Cambridge: Harvard University Press.

- 2005. "From Realpolitik to Dingpolitik." In Latour and Weibel 2005, 14-41.

Latour, Bruno, and Peter Weibel, eds. 2005. Making Things Public: Atmospheres of Democracy. Cambridge: MIT Press.

Lippmann, Walter. 1922. Public Opinion. New York: Free Press.

- 1927. The Phantom Public. New Brunswick, N.J.: Transaction Books.

Lower, Milton D. 1990. "A Type-of-Product System of National Accounts.” Journal of Economic Issues 24 (2): 371-79.

MacKenzie, Donald. 2007. "Is Economics Performative? Option Theory and the Construction of Derivatives Markets." In MacKenzie, Muniesa, and Siu 2007, 54-86.

MacKenzie, Donald, and Yuval Milo. 2003. "Constructing a Market, Performing Theory: The Historical Sociology of a Financial Derivatives Exchange." American Journal of Sociology 109 (1): 107-45.

MacKenzie, Donald, Fabian Muniesa, and Lucia Siu. 2007. Do Economists Make Markets? On the Performativity of Economics. Princeton: Princeton University Press.

Markoff, J., and Veronica Montecinos. 1993. "The Ubiquitous Rise of Economists." Journal of Public Policy 13 (1): 37-68.

Marres, N. 2005. "Issues Spark a Public into Being: A Key but Often Forgotten Point of the Lippmann-Dewey Debate." In Latour and Weibel 2005, 208-17.

Medvetz, Tom. 2012. The Rise of Think Tanks in America: Merchants of Policy and Power. Chicago: University of Chicago Press.

Miller, Peter. 2004. "Governing by Numbers: Why Calculative Practices Matter." In The Blackwell Cultural Economy Reader, edited by Ash Amin and Nigel Thrift, 179-90. Malden, U.K.: Blackwell.

Miller, Peter, and Nikolas Rose. 1990. "Governing Economic Life.” Economy and Society 19 (1): 1-31.

Mirowski, Philip. 2002. Machine Dreams: Economics Becomes a Cyborg Science. Cambridge: Cambridge University Press.

Mitchell, T. 1991. "The Limits of the State: Beyond Statist Approaches and Their Critics." American Political Science Review 85 (1): 77-96.

—. 1998. "Fixing the Economy." Cultural Studies 12 (1): 82-101.

Nordhaus, William, and James Tobin. 1972. "Is Growth Obsolete?" In Economic Growth, vol. 5 of Economic Research: Retrospect and Prospect, edited by William Nordhaus and James Tobin, 1-80. New York: NBER.

Overseas Development Council. 1980. The United States and World Development. New York: Praeger. 
Pannozzo, Linda, and Ronald Colman. 2009. New Policy Directions for Nova Scotia: Using the Genuine Progress Indicator to Count What Matters. GPIAtlantic. www.gpiatlantic.org/pdf/integrated/new_policy_directions.pdf.

Popkin, J. 2000. "Data Watch: The U.S. National Income and Product Accounts." Journal of Economic Perspectives 14 (2): 215-24.

Porter, Theodore. 1995. Trust in Numbers. Princeton: Princeton University Press.

Posner, R. 2001. Public Intellectuals: A Study in Decline. Cambridge: Harvard University Press.

Rose, N. 1992. "Engineering the Human Soul: Analyzing Psychological Expertise." Science in Context 5 (2): 351-69.

Rose, N., P. O’Malley, and M. Valverde. 2006. "Governmentality.” Annual Review of Law and Social Science 2:83-104.

Sapiro, Giselle. 2009. "Modeles d'intervention politique des intellectuels: Le cas français." Actes de la recherche en sciences sociales 176-77:8-31.

Siegfried, John J., and Wendy A. Stock. 1999. "The Labor Market for New PhD Economists." Journal of Economic Perspectives 13 (3): 115-34.

Simmel, Georg. 1950. “The Stranger.” In The Sociology of Georg Simmel, edited by Kurt Lewin, 402-8. New York: Free Press.

Stiglitz, Joseph E., Amartya Sen, and Jean-Paul Fitoussi. 2009. Report by the Commission on the Measurement of Economic Performance and Social Progress. www.stiglitz-sen-fitoussi.fr.

Talberth, John, Clifford Cobb, and Noah Slattery. 2007. The Genuine Progress Indicator 2006: A Tool for Sustainable Development. Oakland, Calif.: Redefining Progress.

Vanoli, André. 2005. A History of National Accounting. Amsterdam: IOS Press.

Walker, P. 1979. Between Labor and Capital. Hassocks, U.K.: Harvester.

Ward, Michael. 2004. Quantifying the World: UN Ideas and Statistics. Bloomington: Indiana University Press.

Waring, Marilyn. 1988. If Women Counted: A New Feminist Economics. New York: Harper.

Wherry, Frederick F. 2004. "International Statistics and Social Structure: The Case of the Human Development Index." International Review of Sociology 14 (2): 151-69.

Yonay, Yuval. 1998. The Struggle over the Soul of Economics. Princeton: Princeton University Press.

Zolotas, Xenophon. 1981. Economic Growth and Declining Social Welfare. New York: New York University Press. 